\title{
Environmental and Cultural Factors Influencing Parthian Archaeological Site Distribution in the Sarfirouzabad Plain of Kermanshah, Northwest of Iran
}

\author{
Kamal Aldin Niknami ${ }^{1}$, Hajar Irandoust ${ }^{1}$, Akram Tahmasebi ${ }^{2}$ \\ ${ }^{1}$ Department of Archaeology, University of Tehran, Tehran, Iran \\ ${ }^{2}$ Iranian Tourism and Heritage Organization, Kermanshah, Iran \\ Email: kniknami@ut.ac.ir
}

Received October 7, 2012; revised November 5, 2012; accepted December 3, 2012

\begin{abstract}
Sarfirouzabad district, located in the Kermanshah province, is an eastward extension of Mahidasht Plain, one of the archaeologically well-known regions of the Central Zagros flanks. The area is surrounded by parallel mountain chains of Sefid on the north and Nessar on the south, the main water source of which is Ab-i Marik River flowing in the middle of the valley westward. The region has various environs such as alluvial deposits, steppe, wooden and barren foothills. The first archaeological survey of the region carried out in 2009, exploring 339 sites ranging from Paleolithic to the Islamic periods. 97 of the investigated sites were assigned to the Parthian period, one of the historical periods of ancient Iran. The study aimed to analyze spatial distribution patterns of the Parthian sites of the region as well as the nature and relationship between natural and cultural factors influencing on that distribution, using GIS technology. The results show that the distribution of the Parthian sites on the Sarfirouzabad district were influenced by a combination of natural and cultural factors and we can realize two kinds of patterns in their distributions over the region.
\end{abstract}

Keywords: Central Zagros; Sarfirouzabad; Parthian Sites; GIS Technology; Spatial Distributions

\section{Introduction}

Firouzabad district is a marginal region located in the southwest of Kermanshah city, in the southern part of Great Khurasan Road (Figure 1). It consists of three villages; Sarfirouzabad, Osmanvand, Jalalvand. Totally this region contains the eastern extension of the so called Mahidasht plain. The Sarfirouzabad area could be divided into three regions including a central flat plain which is bounded by two mountain chains. The study area is about $1000 \mathrm{Km}^{2}$, and this study regards the settlement distribution patterns of the region in the Parthian period. Overall, 339 sites were identified by the accomplished surveys, of which 97 sites dating to the Parthian period were described, and data was gathered from those sites to create a databank for GIS analysis (Figure 2). As the quantity of sites show, the Parthian period is one of the most important stages of cultural history in the region.

Parthian dynasty (ca 250 B.C.-225 A.D.) as one of the longest dynasties of ancient Iran has been originated from the eastern regions of Caspian Sea and lasted for five centuries [1]. The Parthian habitats of Western Iran witnessed a considerable decline in density, population growth and number of the settlements [2].
The study is to show site distribution patterns of the region in the Parthian period, main characteristics of the Parthian settlements of the Central Zagros, as well as measuring the impact of natural factors on their formation processes. The restoration and reconstruction of sites by GIS spatial analysis helps us better understanding the quality of man-earth relation in the study period. The objective of this study is to discuss the spatial distribution features of Parthian settlements in the Sarfirouzabad district.

\section{Study Area and Methods}

\subsection{Study Area}

Sarfirouzabad district located in the Kermanshah province encompassing various environs suitable for human settlement from Paleolithic times to the present [3-5]. The main water source of the region, Ab-i Marik, flows in the middle of the valley westward. The area is bounded by Kuh-i Sefid Mountain in the north and Kuh-i Nessar Mountain in the south.

Deposition of Kouh-i-Sefid consists of Neritic facies while block of Kouh-i-Nesar has deep facies and consists of Marly limestone belonging to the deep area of the sea. 


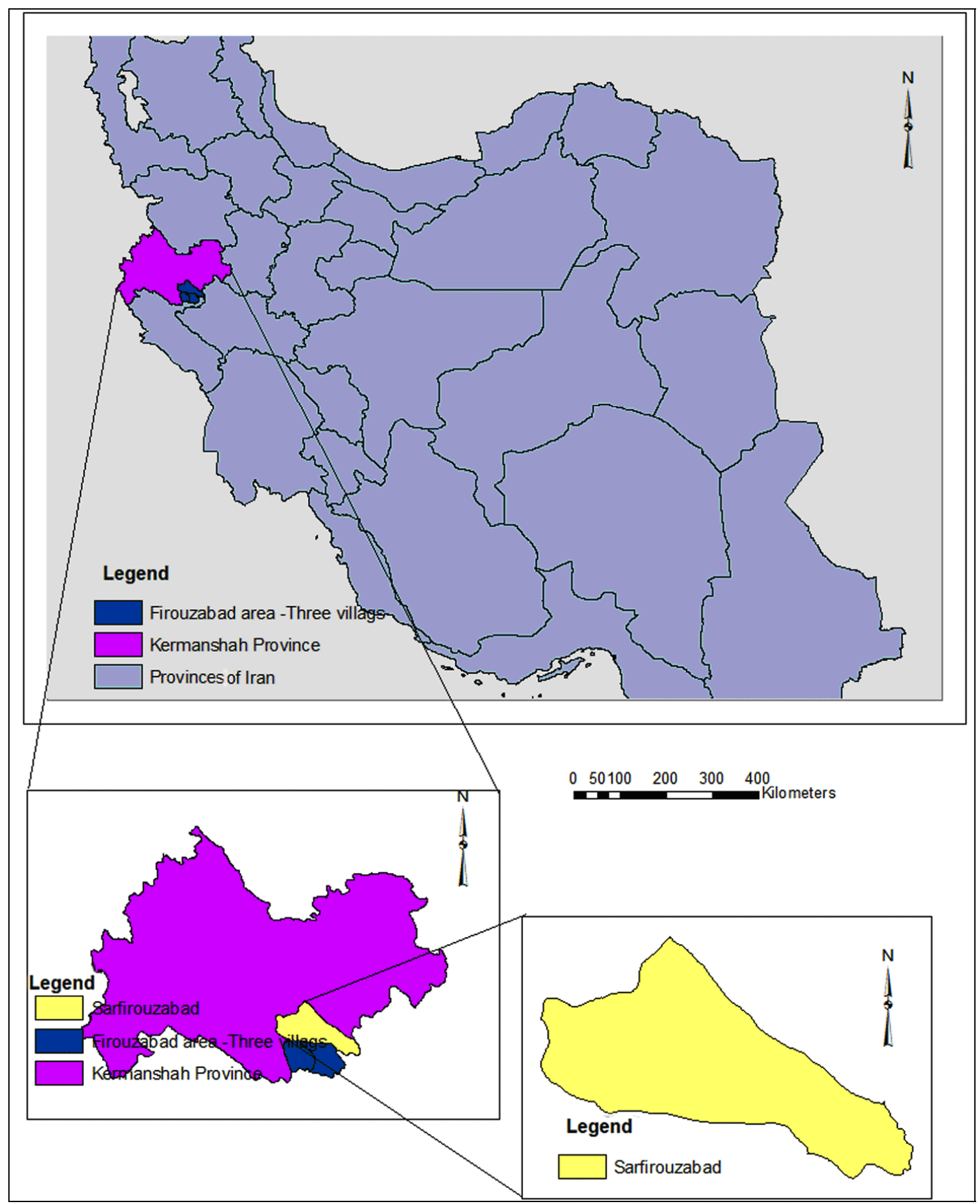

Figure 1. Map of Iran and location of Sarfirouzabad study area.

Separated boundary of these two blocks is a young over thrust which continues parallel to Kouh-i-Sefid and from northwestern to southeastern. in block of Kouh-i-Sefid zone the collisions of Iranian and Arabian plats and their tectonic processes decreased the depth of the basin resulted in a shallow carbonate environment was produced by assemblage of benthic fauna and sometime giving rise to local patch reef in suitable physical and chemical condition. Sedimentary sequence resulted from the regressive processes is evident in the zone, however, were accompanied by beginning of the formation of limestone member of Kermanshah. Above regressive sequence there has been a short retention phase which results from sedimentary basin fluctuations or function of area's faults. 


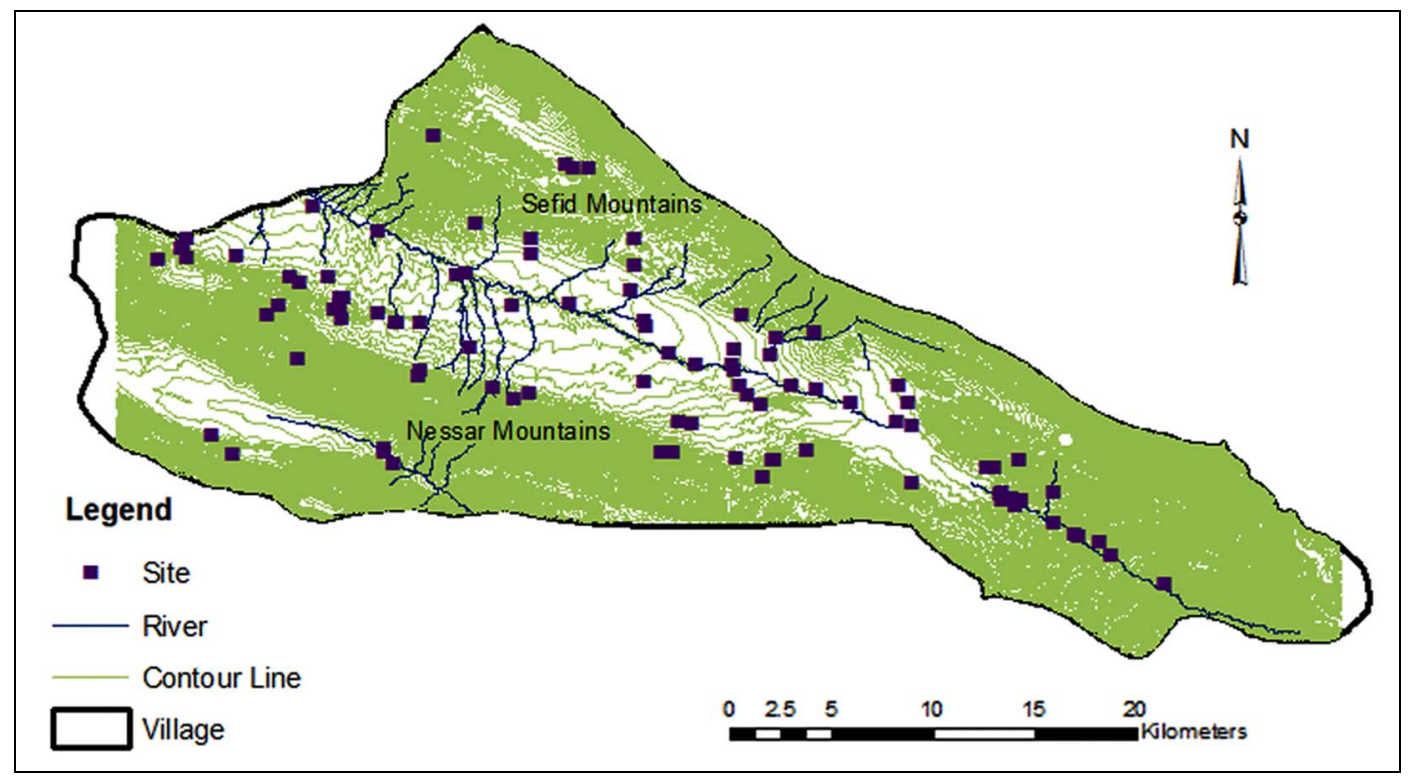

Figure 2. Map of Sarfirouzabad study area indicating location of sites discovered during ground survey.

In Quaternary the study area consists of old alluvium, Marly sediments, existing colluviums in slopes and alluvials, which are located in valleys and river bed area [6].

The climate of the area is to a large extent subjected to particular climatic influences. The thermal climate closely resembles those of higher zones in the east Mediterranean Mountains. A considerably lower winter temperature in this zone and the long distance from the sea increases continental characteristics so they do not support Mediterranean vegetation. The temperature varies both with altitude and latitude. The extensive oak forests on the higher ridges is the vegetational characteristic of the zone and a relatively heavy and reliable rainfall in the areas of Zagros allows sedentary agriculture though most of the areas have been exploited by tribal groups with an economy based on herding. The main tribal groups occupying this area include is still engaged in transhumant herding. In recent years the establishment of agricultural extension services and road construction programs are leading to increased sedentary cultivation.

According to the identification made by the archaeological survey conducted in the area, different parts of it were settled in different periods by humans [7]. This study focuses on the Parthian settlements of the area which include 97 archaeological sites.

\subsection{Data Sources}

A database of Parthian sites was established based on Sarfirouzabad sites data, Sarfirouzabad topographic, environmental as well as administrative maps. The sites data were acquired based on an investigation that was carried out by the Iranian Cultural Heritage and Tourism Organization and one of us (Niknami) from Tehran Uni- versity in 2008.

\subsection{Methods}

The GIS database covers an area of about $1000 \mathrm{~km}^{2}$, covering the majority of the Sarfirouzabad and its immediate environs. The current basic raster and vector layers of the GIS data base include: elevation (derived from the various relevant for example geological, hydrological and topographic 1:50,000 maps) as well as archaeological sites and field survey transects (from project surveys and other sources). Additional derived data layers showing different distance categories, or buffer zones, from: roads, streams, faults, archaeological sites, and ancient roads were then generated from the data above. Additional data have recently been added that were derived from the 1:50,000 maps, including reclassifications and distance measurements from sites, ancient roads, and hydrology. In all there are currently over 100 point, vector, and raster data layers in the database. These data are used to conduct a variety of analyses including:

1) Point Destiny Analysis used to estimate the spatial distribution of sites; 2) Distance Analysis used to reveal the spatial structure of sites in relation to environmental features; 3) 3D Analysis based on Digital Elevation Model (DEM) and contours was done to get microgeomorphologic features of the sites.

\section{Spatial Distribution of the Sites}

\subsection{Distributional Features of Sites}

The Parthian sites of the region were mainly located close to the main streams of the valley (Ab-i Marik and Geshan). According to Distance Analysis, about the half of 
the sites distributed obviously with the $50 \mathrm{~m}$. distance from the rivers; no one of the studied sites were far off more than $350 \mathrm{~m}$. from the rivers. All of the Parthian sites of the region distributed along the river in a linear pattern showing a remarkable dependancy on the main streams of the valley.

\subsection{Distribution Directivity of Sites}

It seems that the settlement pattern of Parthian sites in the valley firstly were given order by environmental factors which here we classify them as follow:

1) River valley directivity. Main stream of Sarfirouzabad district is Ab-i Marik, flowing in the center of the valley westward. Almost all of the Parthian sites distributed along the streams of the region. Most of them located in the central and eastern limits of Ab-i Marik along the both sides of it (Figure 3). As the investigations indicated, the western parts of the main river joining to the

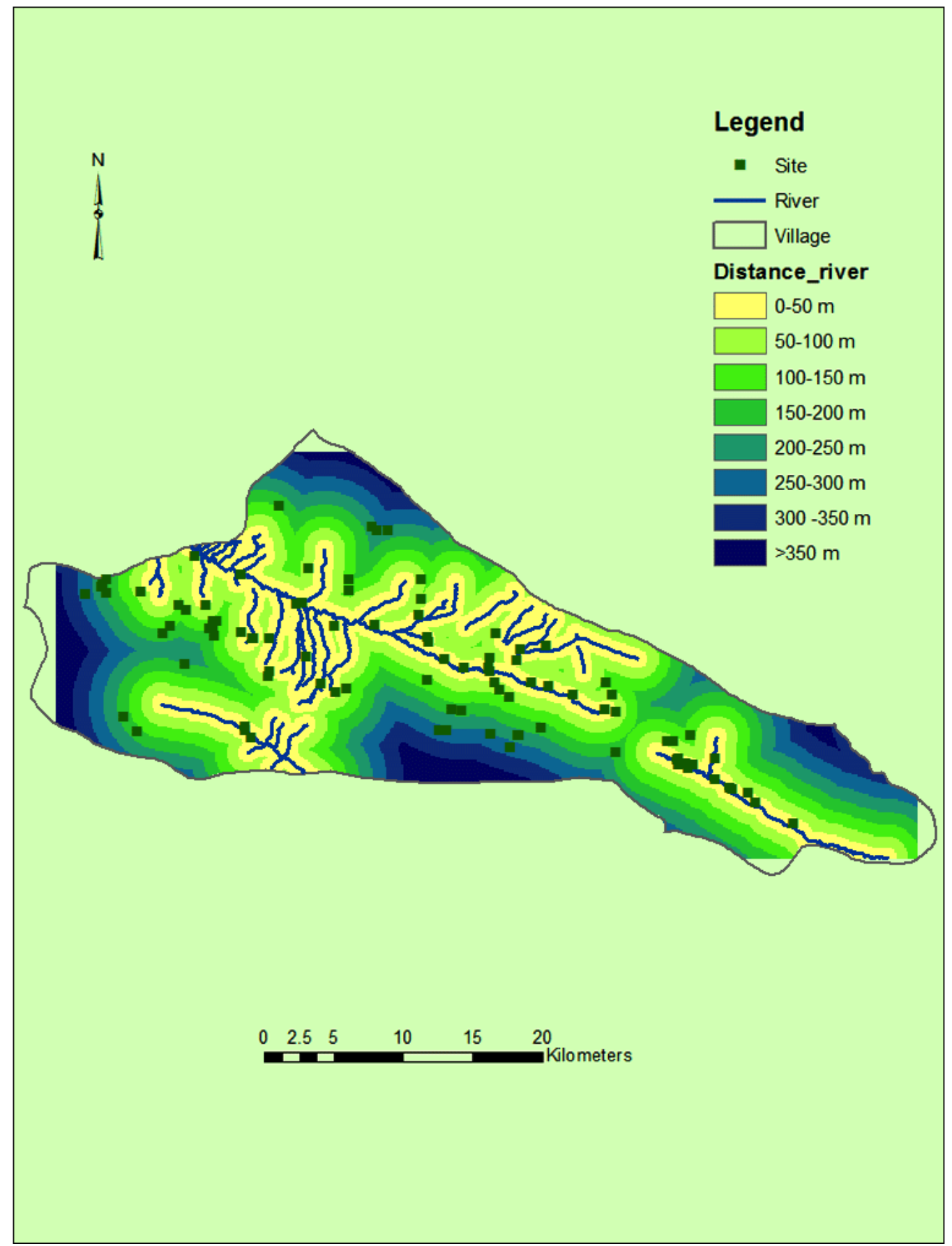

Figure 3. Input environmental layer: Distance of sites to the water system. 
lower part of the plain of Mahidasht, there were nearly no Parthian sites were recognized but about a large number of sites were to have been seen along the temporary streams of higher altitutes, far from the alluvial bed of the river.

2) Foothills directivity. The area has a height of 1000 to $3000 \mathrm{~m}$. above the sea (Figure 4). About 67\% of the Parthian sites distributed around the lower parts of 1000

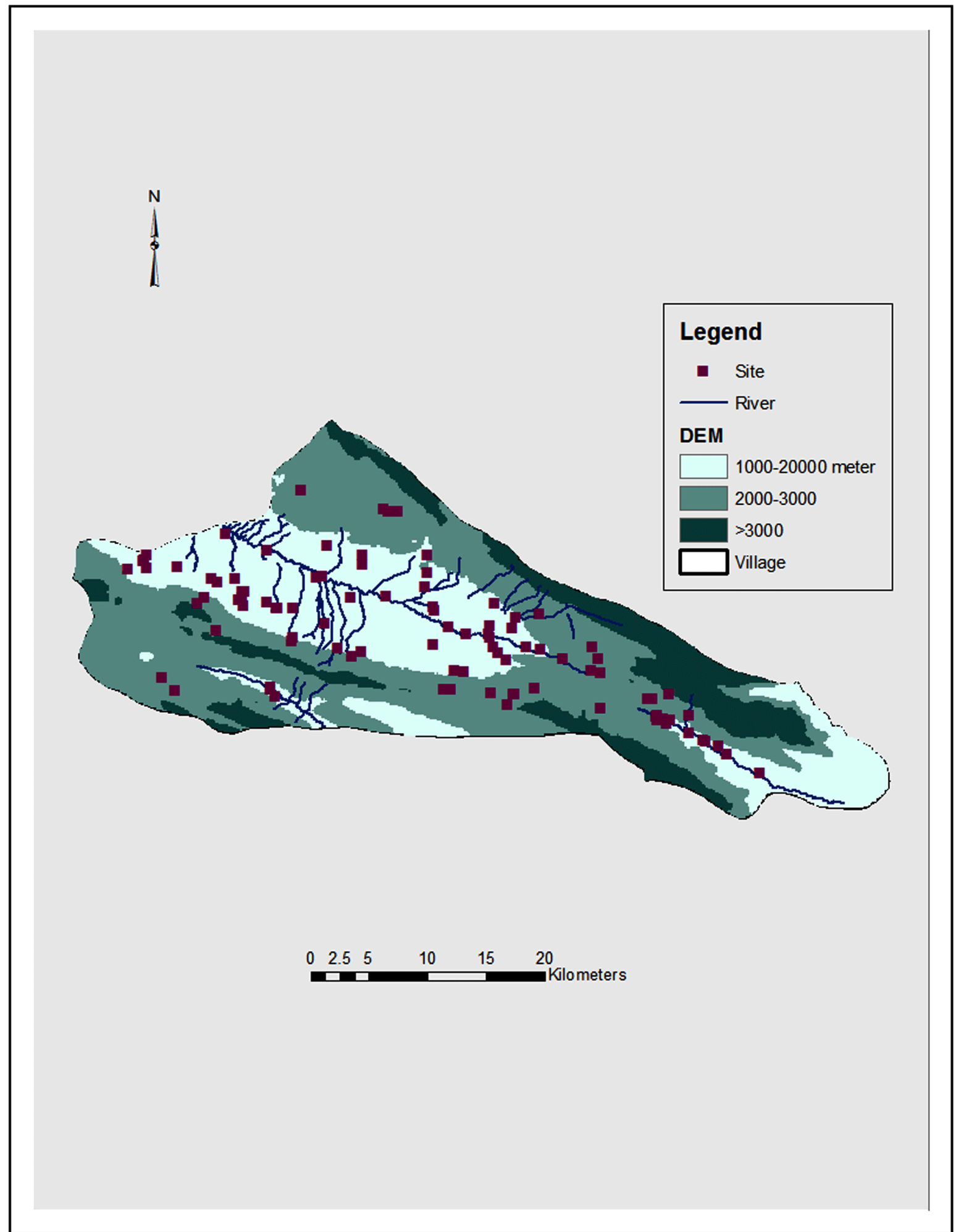

Figure 4. Input environmental layer: Setting of sites above see levels. 
to $2000 \mathrm{~m}$ above the sea. There have been suitable environmental conditions proper to do different livelihood activities such as agriculture and stockbreeding. Only 33\% of the sites distributed in the areas upper than $2000 \mathrm{~m}$. above the sea. The region in these elevations has at least two environs including steppe and woodlands. Only 6 parthian sites were located close to the woodlands. No Parthian site was found at a height of more than $3000 \mathrm{~m}$. The steep slopes and drastic erosion in these altitudes prevent formation of proper environment and hence the absence of the environmental indicators such as prolific lands and suitable pastures for the stockbreeding is the main element to decentralize density of populations in the such areas (Figure 5).

3) Soil directivity. $72 \%$ of the Parthian sites were distributed in areas with $0^{\circ}$ to $20^{\circ}$ slopes, mainly located in the lower parts of the region. Such slopes fore some reasons (i.e. water preservation) are generally considered to be appropriate for agricultural activities. As in such degree of slopes the amount of large grained soil textures are almost rare and the deep small size flake soil with the little calcic brown soil calcareous brown on the soil will appear which make it suitable for the prolific agricultur. Only 4 Parthian sites were to have been in the land slopes of $5^{\circ}$ to $8^{\circ}$. This slope contains the foothills which most of them have a rather front slope with high-lying and low-lying lands. They have shallow and young soil with large flakes, called the eluvium and eboulis. In these lands, if the unevenness status and the soil quality were proper, a scanty agriculture would be possible, mainly achieved by the rural cattlemen or migrating nomads of the front foothills. These regions are the best summer pastures for migrating nomads.

4) Main route directivity. As many of the routes of the Zagros flanks are natural tracks of the valleys and intermountainous areas, their communicative values would be stable through long time periods from prehistoric onwards. So, the study of their relation to the archaeological sites can help us to understand the degree of regional and inter-regional interaction structures and its transformation through a long term process [8]. Among the investigated Parthian sites of the region, about $72 \%$ of them distributed on the limits of 500 to $1000 \mathrm{~m}$. distance from the main routes. The observation indicates that most of the Parthian sites were dependent on the communicative routes of the Sarfirouzabad district (Figure 6).

\section{Discussion}

Parthian sites of the region could be divided into two groups according to their locations in different environmental zones. Consequently, the effects of environmental factors on the Parthian sites should be different on the

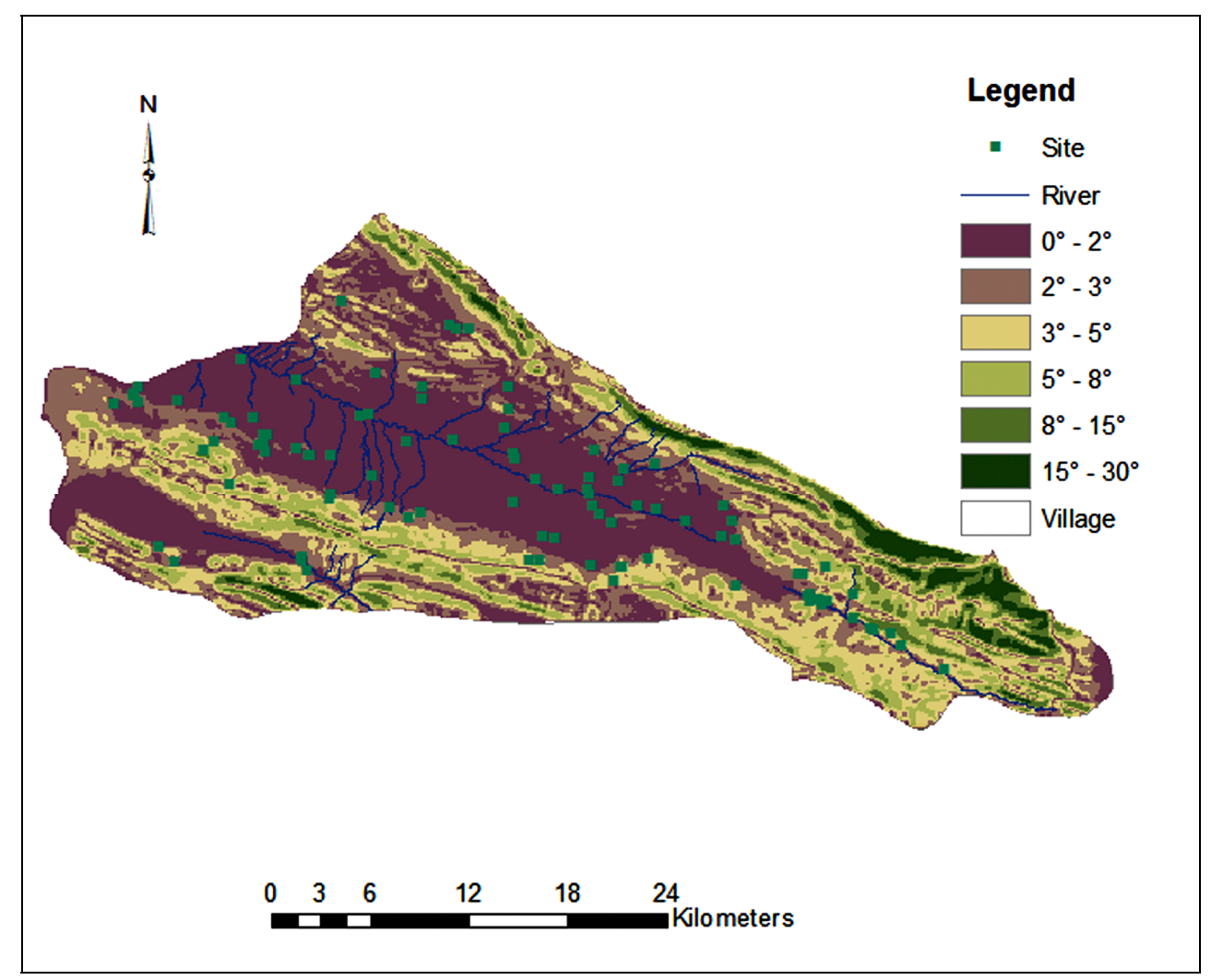

Figure 5. Input environmental layer: Setting of sites on slopes. 


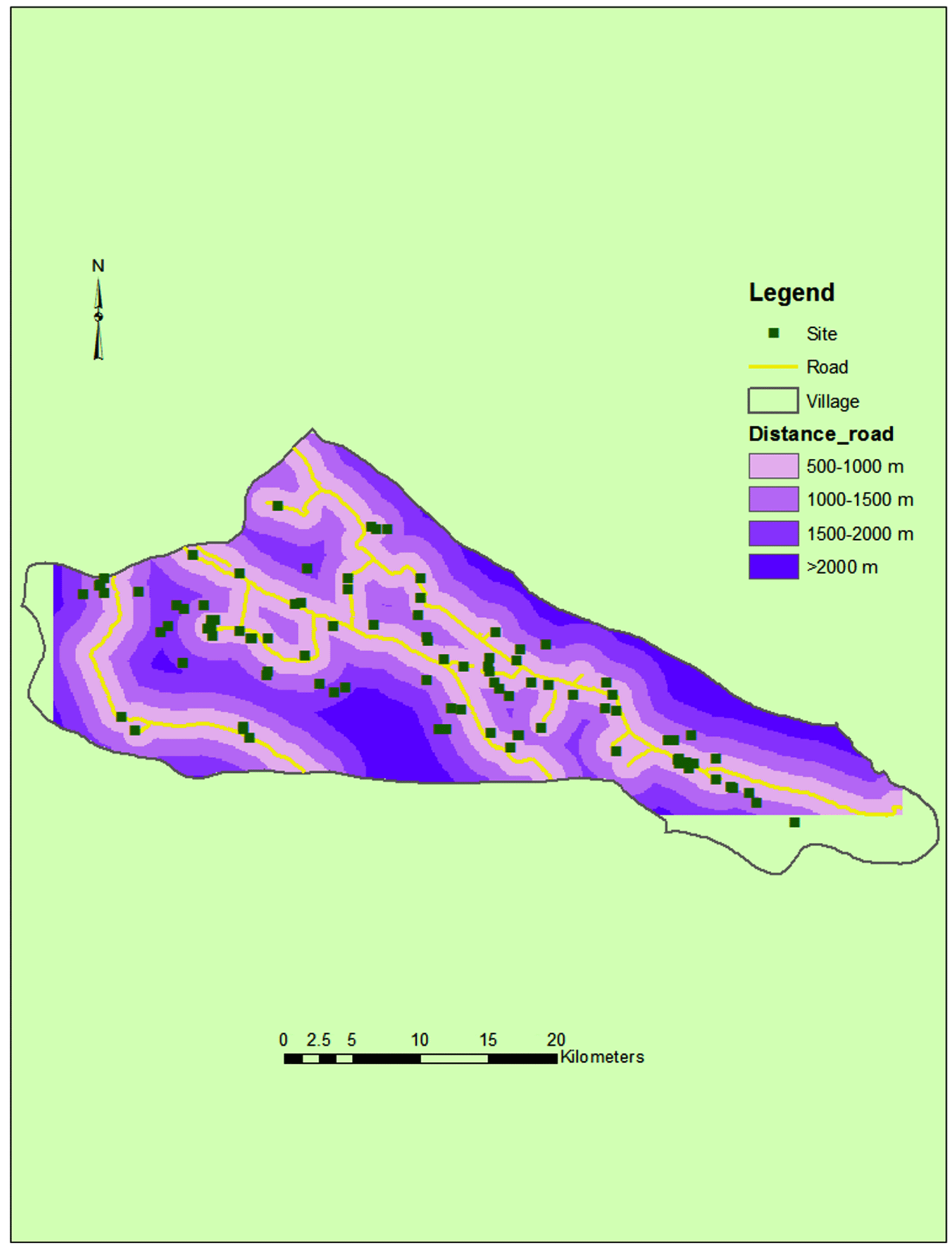

Figure 6. Input environmental layer: Distance of sites to the natural connection routes.

basis of their distribution in various environmental conditions of Sarfirouzabad district. On the other hand, the sites were affected also by human economic and social structures of the period on the basis of production capabilities.

\subsection{Environmental Distribution Factors}

One of the main characteristics of settlements patterns in ancient times was their high dependency on the natural and environmental factors resulted from the lower production potentiality of the man. So, the natural factors at 
that times played a more significant role in adaption of human settlements in the ecological zones.

1) Ecological zones. Sarfirouzabad district has at least three ecological zones. 67.1\% of Parthian sites in the region distributed in a linear pattern along the limits of the main river, where alluvial deposits provide a prolific condition for agriculture to be affective. 32.9\% of other Parthian sites distributed over the lands between the limits of main river and the higher foothills. The extensive presence of springs and marshes in this zone is shown in Figure 2. This phenomenon occur at the result of the tectonic pressures and orogency movements of the calairelimestone which cause the leaks and cracks in the stones and so in this way the ground waters gush through these cleavage and joint. The zone is a kind of mountainous steppe ones. If the unevenness status and the soil quality are proper. in this area, low agriculture can be resulted in production too, and the rural stockbreeders and migrating nomads these foothills.

The zones of higher than $3000 \mathrm{~m}$. above the sea are empty of Parthian sites. The steep slope, violent attrition and narrow valleys, high mountains and summits with the slope of $15^{\circ}$ to $30^{\circ}$ as well as the maximum distance of 300 to $350 \mathrm{~m}$ from the limits of the river-valley are among the environmental characteristics of the zone. Our recent research results from an intensive survey and modeling effort based on classification and predictive modeling of archaeological site distribution using GIS device in the Central Zagros region [9], indicated that densities of sites were related to the environmental variables of the region such as elevation, soil classes and distance to resources. We found that people mainly during prehistory preferentially selected their settlement areas at a moderately elevated part of the region (1500 - 2000 above sea level), and at a moderate cover of perennial vegetation as well as a short distance to the water supplies. Thus the selection of sites by ancient inhabitants may be driven, in part, by lands physical characteristics and water resources, which themselves may follow a clustered pattern.

2) River. More than half of the Parthian sites of the region deeply connected with the main river of the middle of the valley. Permanent streams are among the necessary preriquiste of extensive agriculture. It seems that many of the Parthian inhabitants of the region were dependent fully on agriculture and village living way of life. On the other hand, a combination of narrow agriculture and stockbreeding was possible in the lands between the middle of valley and foothills; suitable for settling of migrating nomads.

\subsection{Cultural Distribution Factors}

Some of the factors affecting sites distribution over the region during the ancient Parthian period were cultural and human-aided due to the increasing capability of pro- duction in the historic times:

1) Main route and transportation. The Parthian sites of the Sarfirouzabad district could be divided according to their distance from the communicative roads. Since the communicative roads of the region are mainly natural tracks of the intermontainous valleys, distribution of the ancient settlements relating to them can be a sign of settlers tendency to be connected with the populations of other regions. As such, distribution of $67.1 \%$ of the Parthian sites on the limits of the main routes of the region show their necessity to access them. So the region had an interregional interaction during the period. On the other hand, about $32.9 \%$ of the Parthian sites were located in a distance of 1000 to $2000 \mathrm{~m}$. from the main routes. It may be so as a result of impermanent character of this kind of sites due to the different economic structure of them (which would be related to the nomadic pastoralism).

2) Economic structure. The Parthian sites of the region in term of their distribution show two different economic structure affecting their location in the district. A group of the sites were located on the limits of the main river and would be permanent villages mainly dependent on the extensive agricultural production. Their dependency on the main river were reasonably an adaptive means to fight against periodic drought of the Zagros flanks by adopting irrigation agriculture. Another land use pattern of the period led to a different economic structure of the district suitable for pastoralism. These kind of sites were not controlled by water system and expanded to some areas with fertile soil but not natural permanent water resources, such as high-altitute lands.

\section{Conclusions}

Knowledge of the environmental variables influencing activities of original inhabitants is used to produce GIS layers representing the spatial distribution of those variables. The GIS layers are then analyzed to identify locations where combinations of environmental variables match settlement patterns observed in the area (e.g. see references in [10] and the location of archaeological sites patterning throughout a landscape [11]. This patterning is a result of past people's tendency to interact with the landscape in "favorable" settings. Favorable settings refer to sites that are preferred over other locations because of specific landscape characteristics (e.g., proximity to water resources, access to trade routes and topographic setting). Certain variables, either environmental or social, within the landscape can produce patterning. This patterning exploit in attempt to explain the relationship between locational characteristics and archaeological sites [12].

Our results show two different types of sites distributional patterns in the region during the Parthian period. The distribution of the sites was influenced by natural 
and cultural factors. On the one hand, there were settlements scattered in a linear pattern on the limits of the main River of the valley maily because of its fertile soil, permanent water and easy access to the main roads. The geography of the environment is such that we can infer that the low laying valleys in mountainous areas could have affected the free movement of the people in the past and therefore, the movement of the people naturally followed the natural course of the rivers. Plant features of the area coupled with abundance of water sources made for a relative density of population.

On the other hand, there were settlements scattered on the higher and less favourable lands which gives way to developing of specialized modes of subsistence such as pastoralism [13] by nomad pastoralists. Both kinds of the sites were influenced by a combination of natural and human factors. Distribution of the Parthian sites over the region presented disciplines such as river valley directivity, foothill directivity, soil directivity and main route directivity.

The application of GIS technology in the study of archaeological sites lead to a better understanding of the relationships between natural and human factors in locationg and distribution of ancient sites. The results of such a study would be also contributed to the further researches about the man-land interrelationship in a regional scale during a particular time or through a long term process.

Again, archaeological challenges in the region-such as this research-would be comprehended by considering the effect of socio-economic and political behaviors on the formation of archaeological sites. But it is very difficult to observe such behaviors by the conventional method alone [14].

\section{Acknowledgements}

Appreciation is offered to the Iran National Science Foundation (INSF) for a grant to collect site data which were used for this research. The authors would like to thanks all the members of the survey team for their kindly cooperation. Grateful thanks to the Cultural Heritage Organization of Kermanshah that provided access to site locations.

\section{REFERENCES}

[1] Y. Mohammdifar, “The Archaeology of Parthian,” SAMT, Tehra, 2006.
[2] R. J. Wenke, "Western Iran in the Partho-Sasanian Period: The Imperial Transformation,” In: F. Hole, Ed., The Archaeology of Western Iran, Settlement and Society from Prehistory to the Islamic Conquest, Smithsonian Series in Archaeological Inquiry 1, Washington, 1987, pp. 251-282.

[3] H. L. Dibble "Le Paleolithique Moyen Recent du Zagros," Bulletin de la Societe Prehistirique Francaise, Vol. 90, No. 4, 1993, pp. 307-312. doi:10.3406/bspf.1993.9599

[4] E. F. F. Henrickson, "The Late Chalcolithic Period in the Central Zagros Highlands,” Paleorient, Vol. 15, No. 1, 1989, pp. 288-293.

[5] L. D. Levine and M. A. McDonald, "The Neolithic and Chalcolithic Periods in the Mahidasht," Iran, Vol. 15, 1977, pp. 39-50.

[6] M. Yousefi Rad, "Dynamic Stratigraphy of Upper Cretaceous in Northwest Zagros (Kermanshah)-Iran,” Scientific Research and Essays, Vol. 6, No. 28, 2011, pp. 59105916.

[7] I. Brooks, L. D. Levine, and R. C. Dunnell, "Alluvial Sequence in Central West Iran and Implications for Archaeological Survey," Journal of Field Archaeology, Vol. 9, No. 3, 1982, pp. 285-299.

[8] I. Brooks, “The Physical Geography, Geomorphology and Late Quaternary History of the Mahidasht Project Area, Qara Su Basin, Central Western Iran,” ROM Mahidasht Project Report 1, Royal Ontario Museum, Toronto, 1989.

[9] K. A. Niknami and M. R. Saeedi Harsini, “A (GIS)-Based Predictive Mapping to Locate Prehistoric Site Locations in the Gamasb River Basin, Central Zagros, Iran,” In: S. Campana and M. Forte, Eds., From Space to Place, BAR International Series S 1568, 2006, pp. 249-255.

[10] K. L. Wescott and R. J. Brandon, "Practical Application of GIS for Archaeologists, A Predictive Modeling Toolkit,” Taylor and Francis, London, 2000.

[11] S. C. Parker, "Predictive Modeling of Site Settlement System Using Multivariate Logistics,” In: C. Carr, Ed., For Concordance in Archaeological Analysis: Bridging Data Structure Quantitative Technique and Theory, Westport Publisher, Kansas City, 1985, pp. 173-207.

[12] K. L. Kvamme, “There and Back Again: Revisiting Archaeological Locational Modeling,” In: M. W. Mehrer and K. L. Wescott, Eds., GIS and Archaeological Site Modeling, Taylor and Francis, London, 2006, pp. 4-37.

[13] T. J. Wilkinson, “Archaeological Landscapes of the Near East,” University of Arizona Press, Tucson, 2003.

[14] G. Lock and T. Harris, "Enhancing Predictive Archaeological Modeling: Integrating Location, Landscape and Culture,” In: M. W. Mehrer and K. L. Wescott, Eds., GIS and Archaeological Site Modeling, Taylor and Francis, London, 2006, pp. 41-62. 